\title{
Mechanic and Enecánica e Energy Grinding of AISI 4340 steel with interrupted cutting by aluminum oxide grinding wheel
}

http://dx.doi.org/10.1590/0370-44672014680070

\section{Hamilton Jose de Mello}

Físico, Doutorando em Engenharia Mecânica pela Faculdade de Engenharia de Bauru, UNESP Universidade Estadual Paulista Júlio de Mesquita UNESP - Departamento de Engenharia Mecânica Bauru - São Paulo - Brazil

hamilton@feb.unesp.br

\section{Diego Rafael de Mello}

Graduando em Engenharia Mecânica pela Faculdade de Engenharia de Bauru, UNESP -

Universidade Estadual Paulista Júlio de Mesquita UNESP - Departamento de Engenharia Mecânica Bauru - São Paulo - Brazil

diego.rafa@hotmail.com

\section{Eduardo Carlos Bianchi}

Professor Titular do Departamento de Engenharia Mecânica da Faculdade de Engenharia de Bauru, UNESP. Universidade Estadual Paulista Júlio de Mesquita UNESP - Departamento de Engenharia Mecânica Bauru - São Paulo - Brazil

bianchi@feb.unesp.br

\section{Paulo Roberto de Aguiar}

Professor Titular do Departamento de

Engenharia Elétrica da Faculdade de Engenharia de Bauru, UNESP.

Universidade Estadual Paulista Júlio de Mesquita UNESP - Departamento de Engenharia Elétrica Bauru - São Paulo - Brazil

aguiarpr@feb.unesp.br

\section{Doriana M. D'Addona}

Professora Assistente da University of Naples Federico II

University of Naples Federico II - Dept. of Chemical, Materials and Industrial Production Engineering

Naples, Campania - Italy

daddona@unina.it

\author{
Retificação do aço AISI 4340 \\ usando corte interrompido com \\ rebolo convencional
}

\begin{abstract}
There has been a great advance in the grinding process by the development of dressing, lubri-refrigeration and other methods. Nevertheless, all of these advances were gained only for continuous cutting; in other words, the ground workpiece profile remains unchanged. Hence, it becomes necessary to study grinding process using intermittent cutting (grooved workpiece - discontinuous cutting), as little or no knowledge and studies have been developed for this purpose, since there is nothing found in formal literature, except for grooved grinding wheels. During the grinding process, heat generated in the cutting zone is extremely high. Therefore, plenty of cutting fluids are essential to cool not only the workpiece but also the grinding wheel, improving the grinding process. In this paper, grinding trials were performed using a conventional aluminum oxide grinding wheel, testing samples made of AISI 4340 steel quenched and tempered with 2, 6, and 12 grooves. The cylindrical plunge grinding was performed by rotating the workpiece on the grinding wheel. This plunge movement was made at three different speeds. From the obtained results, it can be observed that roughness tended to increase for testing sample with the same number of grooves, as rotation speed increased. Roundness error also tended to increase as the speed rotation process got higher for testing the sample with the same number of grooves. Grinding wheel wear enhanced as rotation speed and number of grooves increased. Power consumed by the grinding machine was inversely proportional to the number of grooves. Subsuperficial microhardness had no significant change. Micrographs reveal an optimal machining operation as there was no significant damage on the machined surface.
\end{abstract}

Keywords: External cylindrical plunge grinding, interrupted cut, finishing, microhardness, cutting power

\section{Resumo}

No processo de retificação, muito já se avançou com o desenvolvimento de métodos de dressagem de rebolos, de lubrirefrigeração e de outros mais. Todavia, todos esses progressos foram conseguidos apenas no que diz respeito ao corte contínu, ou seja, o perfil da peça retificada não sofre descontinuidade alguma. Nesse sentido, torna-se necessário o estudo do processo de retificação por corte intermitente (peça com ranhuras - corte descontínuo), pois pouco ou, mesmo, nenhum conhecimento elou estudo foi desenvolvido com esse enfoque, visto que não é encontrado material algum na literatura formal, salvo aqueles em que o rebolo é o detentor das ranhuras. Na retificação, o calor gerado na zona de corte é extremamente elevado. Dessa forma, o uso de fluidos de corte é indispensável para que seja possível refrigerar, tanto a peça, quanto o rebolo e propiciar melhorias na operação de corte, sendo o mais 
comum a utilização de fluido em abundância, tendo em vista que os agentes de arrefecimento e lubrificação são capazes de proporcionar uma retificação mais eficiente. Os ensaios foram realizados com um rebolo convencional de óxido de alúmínio, retificando corpos-de-prova confeccionados com aço ABNT 4340 temperado e revenido com 2, 6 e 12 ranhuras. A operação cilindrica utilizada foi de mergulho, ou seja, o rebolo avança sobre a peça em movimento de rotação. Esse avanço é realizado com três velocidades distintas. Dos resultados obtidos, pode-se observar que a rugosidade tendeu a aumentar, para CP's com mesmo número de ranhuras, conforme foi aumentada a velocidade de mergulho. Os erros de circularidade, assim como a rugosidade, também tenderam a aumentar com o aumento da velocidade de mergulho, para CP's com mesmo número de ranhuras. O desgaste do rebolo tendeu a aumentar conforme aumentados a velocidade de mergulho e o número de ranhuras. A potência consumida pela retificadora foi inversamente proporcional ao número de ranhuras. A microdureza subsuperficial não provocou alteração significativa. E as micrografias revelaram que a usinagem foi satisfatória, pois não houve danos significativos à superficie usinada.

Palavras-chave: Retificação cilíndrica externa de mergulho, corte interrompido, acabamento,microdureza, potência de corte.

\section{Introduction}

Since a long time ago, the external cylindrical plunge grinding operation is widely used in a machining cycle, particularly at the end of it, as it is a traditional finishing process (Klocke et al., 2005). It is able to produce a workpiece with very satisfactory dimensional and geometric features, such as accurate dimensions and reduced values of roughness and roundness. Grinding is normally used for continuous cutting (i.e., grinding of workpiece without discontinuity), while intermittent cutting (workpiece with grooves, slots or other kind of discontinuity) is little known, since formal literature information is scarce. The intermittent cutting operation is usually studied in conventional processes, such as turning (Diniz et al., 2005).

In recent decades, it is possible to observe that technologies, involving machining processes, have achieved great advances, as can be seen in significant changes of machine tools with implementation of a Computer Numerical Control (CNC) (Quintana and Ciurana, 2011). Also according to Quintana and Ciurana, production capacity has grown greatly through development of new concepts, materials, tools and structures with innovative solutions and that all this was achieved due to "knowledge generation", that is, through effort, study and research.

From this assumption, even if processes and machines have undergone certain advances, there is much to improve. This research work aimed to contribute to the little-known intermittent grinding process. A novelty is that there are no tools that provide discontinuous cutting. High efficiency and accuracy machine tools are fundamental in the modern manufacturing processes (Kim et al., 2013).

When compared to other machining operations, grinding can present harmful effects such as rapid grinding wheel wear, greater use of coolant agents and even poor dimensional tolerance, as it involves large specific energy (Fan and Miller, 2006). Furthermore, the biggest problem in the cutting operation is to control heat transferred to the workpiece (Pérez et al., 2008). This is because cutting fluid is not sufficiently supplied at the cutting zone, in which the temperature rapidly increases and causes damage, such as burning and microstructural modification of the machined surface. All these factors have made several researchers seek for possible solutions to such problems. Finally, they were able to demonstrate that intermittent grinding (for grooves on grinding wheel) is a promising method to reduce both the average force of grinding (Fan and Miller, 2006) as well as thermal damage due to its excellent cooling effect (Kwak and $\mathrm{Ha}$, 2001; Alves et al., 2011).

According to Al-Zaharnah (2006), discontinuous cutting is a cutting process in which the tool is now in contact with the workpiece, but sometimes loses this contact (inactive time). It is a process widely used in material machining. In the turning process, for example, there is intermittent cutting when the raw workpiece geometry is not cylindrical, such as a square section bar, or it is cylindrical, but it contains a keyway or a transverse hole (Sanches, 2011). With respect to the milling process, it is also naturally considered an intermittent cutting process, since the various cutting edges on the tool, present cutting cycles; that is, at a given instant it is removing material and afterwards it is not. Thus, there is an intermittent period that benefits the cooling process.

Discontinuous cutting is important due to changes in force characteristics acting on the tool. Coupling and uncoupling between the workpiece and tool generates impacts between them that might cause changes in both the forces involved in the process and the machined surface roughness (Al-Zaharnah, 2006).

With reference to the machining temperature, according Kountanya (2008), for the intermittent cutting process, temperature is lower than for continuous cutting, since the heating periods (material removal) and cooling (no removal) are merged and, by this fact, cutting discontinuity could promote a lower flank / crater wear of the tool extending its service life.

The aim of this study was to verify whether discontinuous cutting, along with conventional method of lubrication and refrigeration (with abundant fluid use), is suitable under various machining conditions (finishing, semi-roughing and roughing) to obtain the best variables (surface roughness, roundness, diametrical grinding wheel wear, power, microhardness and micrograph), and also studying interruption influence (grooves) on the grinding process of AISI 4340 steel, 
quenched and tempered using a conven-

\section{Material and method}

Materials and methods used to

\subsection{Material and testing samples}

Testing samples were made of AISI 4340 quenched and tempered steel of 54

Figure 2.1.a TS with two-groove

Figure 2.1.b TS with six-groove.

Figure 2.1.c TS with twelve-groove.

Figure 2.1.d TS dimensional specification ( $\mathrm{mm})$.

tional aluminum oxide grinding wheel

under various machining conditions.

develop this research work are presented below.

HRc hardness. Figures 2.1.a, 2.1.b and

geometries and Figure 2.1.d their dimen2.1.c show different testing sample (TS) sional specifications.
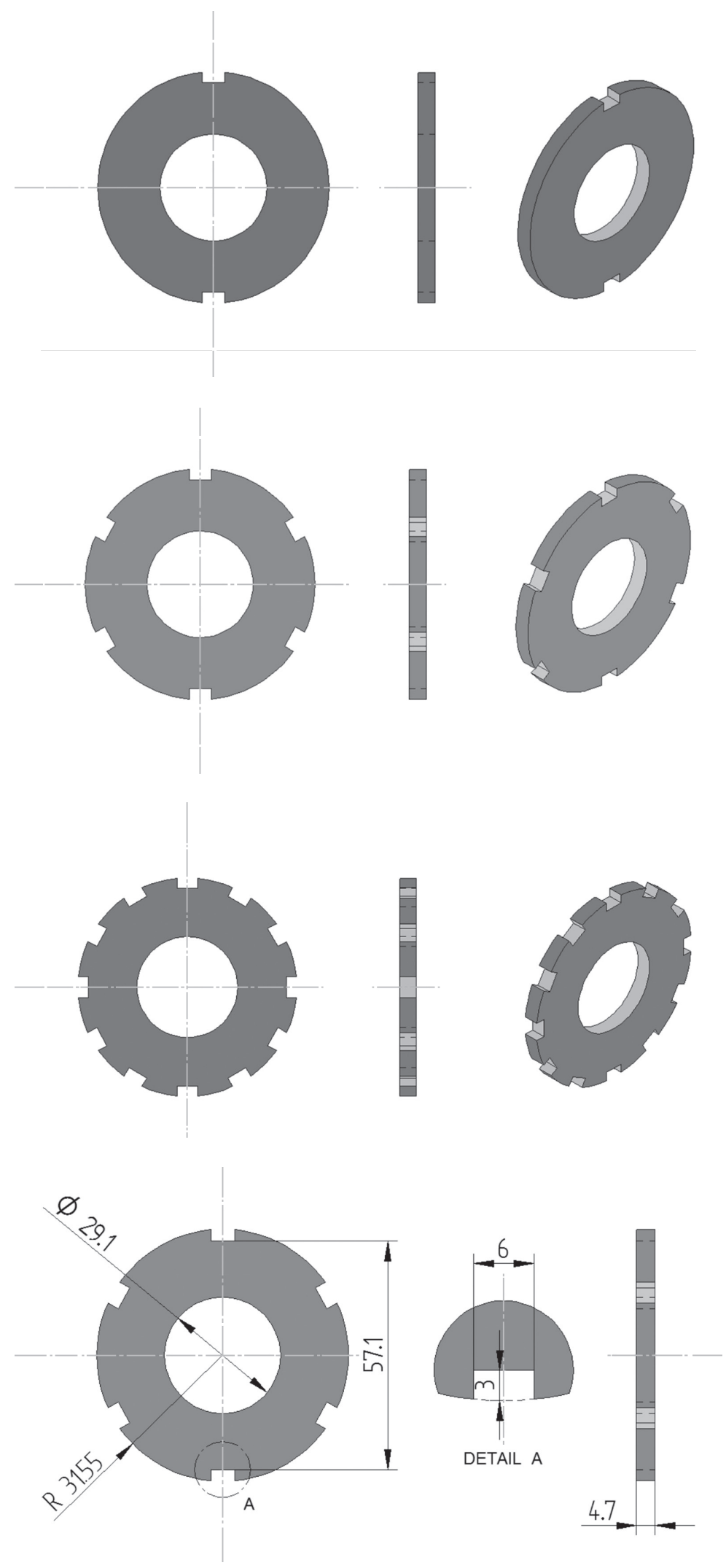
After the machining process required to shape TSs into the specified geometry and dimensions, they were subjected to heat treatment processes, which are quenching and tempering, ensuring them a better hardness (tempering) and toughness (quenching). These treatments were carried out due to the fact that they are greatly used by industries and, thus, it was sought to perform trials as similar as possible to those made in the market.

\subsection{Grinding wheel}

The grinding wheel used in trials has the following specification: RT 355 $\mathrm{mm}$ x $25.4 \mathrm{~mm}$ x $127 \mathrm{~mm}$ (diameter $\mathrm{x}$

\subsection{Experimental method}

For the grinding operation, an external cylindrical plunge grinding machine was used. The TS was placed on an axis, which lay between the grinding edges, allowing the TS's surface to be perpendicular to the wheel plunge. Before contact between the workpiece and abrasive tool, both were rotated in the same direction, in order to remove greater amounts of material, besides having the cooling system turned on for abundance. The grinding wheel cutting speed was $30 \mathrm{~m} / \mathrm{s}$ and workpiece rotation $\left(\mathrm{n}_{\mathrm{w}}\right) 204 \mathrm{rpm}$. Grinding depth was $5 \mathrm{~mm}$, with $0.1 \mathrm{~mm}$ penetration depth between each spark-out time (about $3 \mathrm{~s}$ ), infeed rates $\left(V_{f}\right)$ of $0.25-0.50-0.75 \mathrm{~mm} / \mathrm{min}$ for each one of the three TS types. At each dressing operation, two trials were conducted in different cutting surface areas of the grinding wheel. Dressing was done with a conglomerate type dresser, whose penetration was $40 \mu \mathrm{m}$ and lateral displacement speed $=100 \mathrm{~mm} / \mathrm{min}$.

To analyze the diametrical wear of the grinding wheel, abrasive tool imprints were made before its dressing into pre-machined cylinders at an infeed rate of $0.25 \mathrm{~mm} / \mathrm{min}$, at which improved accuracy was promoted. Using a proper equipment-aid, wear was measured by means of these imprints.

Then, theTS's were subjected to soaking in chemicals to become the clean-

\section{Results and discussion}

This section presents the experimen-

\subsection{Surface roughness}

Surface roughness behavior ( $\mathrm{Ra}$ ) is presented in Figure 3.1.a according
In external cylindrical plunge grinding, the grinding wheel runs perpendicularly forward to the ground surface. The grinding wheel is usually wider than the workpiece length, being possible to grind simultaneously various surfaces by mounting several grinding wheels or by profile grindings with the grinding wheel moulding the appropriate profile (Diniz et al., 2008). The process can be compared to a mass-spring system, since

thickness $\mathrm{x}$ bore diameter); AA 150 L6 VS (where AA: soft white aluminum oxide; 150: fine-grained; L: medium hardness;

est possible in order to perform roundness and roughness analyses, using tweezers as an aid to avoid contact with the natural fat on hands. Therefore, they were immersed in the following baths: kerosene or turpentine; thinner; ethyl or hydrated alcohol; and methyl alcohol. The purpose of this sequence is to remove coarse impurities, such as coolant, by solvents with greater power of removal, such as kerosene and thinner.

For roundness evaluation, each TS was placed in the equipment, performing three measurements each, where the initial contact position of the workpiece's touch-sensitive edge differs by $120^{\circ}$ from the previous contact point. Tayrond 31c equipment (Taylor Hobson brand) has been used for roundness evaluation.

In a similar way, the surface roughness ( $\mathrm{Ra}$ ) was measured; that is, three measurements were made at each TS, each differing $120^{\circ}$ from the previous. The equipment used was the Surtronic $3^{+}$ (Taylor Hobson brand).

Subsequently, testing samples were removed and embedded in resin to carry out metallographic and polishing techniques, enabling microstructural (by photomicrographs) and microhardness analyses.

Microhardness was measured on a Vickers scale using a 300-g load, which was selected to provide a better the infeed rate of the grinding wheel on the workpiece causes elastic deformations in the machine base by lack of rigidity of the system, particularly of the machine tool. In this way, it is necessary to create a period without forward runs, called sparking time or spark-out. During this period, deformations are gradually eliminated, material is removed, and delay eliminated, attaining the desired dimensions (Baldo, 1994; Hassui, 2002).

6: basis; V: vitrified bonding; S: manufacturer private brand) and a cutting speed $\left(\mathrm{V}_{\mathrm{s}}\right)$ of $30 \mathrm{~m} / \mathrm{s}$.

view of indenter imprinted diagonals, becoming more precise. Three series were conducted for each TS, and each series represented by 5 microhardness measurements equidistant from one another and below the machined surface (indentation performed from surface toward center). This distance is equal to twice the longest imprinted diagonal. In preliminary trials, this distance was $60 \mu \mathrm{m}$ since in all imprints, the major diagonal was around $29 \sim 30 \mu \mathrm{m}$.

Grinding wheel wear was measured by using a surface roughness measuring device. In a previously machined cylinder, an imprint was made, and this cylinder got the same grinding wheel profile. This "imprint" is nothing more than grinding wheel penetration into the cylinder (in this case, $0.1-\mathrm{mm}$ penetration at an infeed rate of 0.25 $\mathrm{mm} / \mathrm{min}$ and full cut depth of $1.0 \mathrm{~mm}$ ). Thus, the device is set to scan a given length and, in this way, detects depth changes of the imprint, revealing the abrasive tool wear through a software.

The power required by the machine was measured by means of a potentiometer that acquired grinder signals and sent them to the dedicated software (LabView ${ }^{\circledR} 7.1$, National Instruments $\left.{ }^{\circledR}\right)$ in the computer. The file generated by the software was processed in MATLAB® 2012. tal results of the output variables for each

grinding condition. to trials, and their respective standard deviations. 
Figure 3.1.a

Surface roughness due to the grinding wheel infeed rate.

It can be observed that there is a trend of increasing roughness as infeed rate increases for the TS type (same number of grooves). According to Alves et al. (2011), grinding wheel speed affects workpiece surface finishing by means of changing tangential cutting force, which increases surface roughness as the force soars up. Thereby, surface roughness is increased as the infeed rate increases from $0.25 \mathrm{~mm} /$ $\min$ to $0.75 \mathrm{~mm} / \mathrm{min}$. This result can be explained through constant hits between TS and wheel, in such way that at first cut, after going through one of the grooves, the impact causes an increase in cutting force in coupling, resulting in a decrease in surface quality. The higher the infeed rate of the grinding wheel in TS, the more severe the workpiecetool impact and friction are, leading to higher force peaks and greater roughness. Al-Zaharnah (2006) explains that discontinuous cutting is important due to changes in the acting force characteristics of the tool, i.e., coupling and uncoupling between workpiece and

\subsection{Roundness}

Roundness values of the testing

The above results allow to conclude that, as roughness results, there was a trend in roundness increase; i.e., for same TS; as infeed rate increased, roundness increased [roundness can be understood as "oval shape" growth or macro-geometric deviation as described by Agostinho et al., (1981)]. This fact occurs because the higher the speed plunge, the more severe is the cut, which makes the workpiece undergo increasingly intense compres-

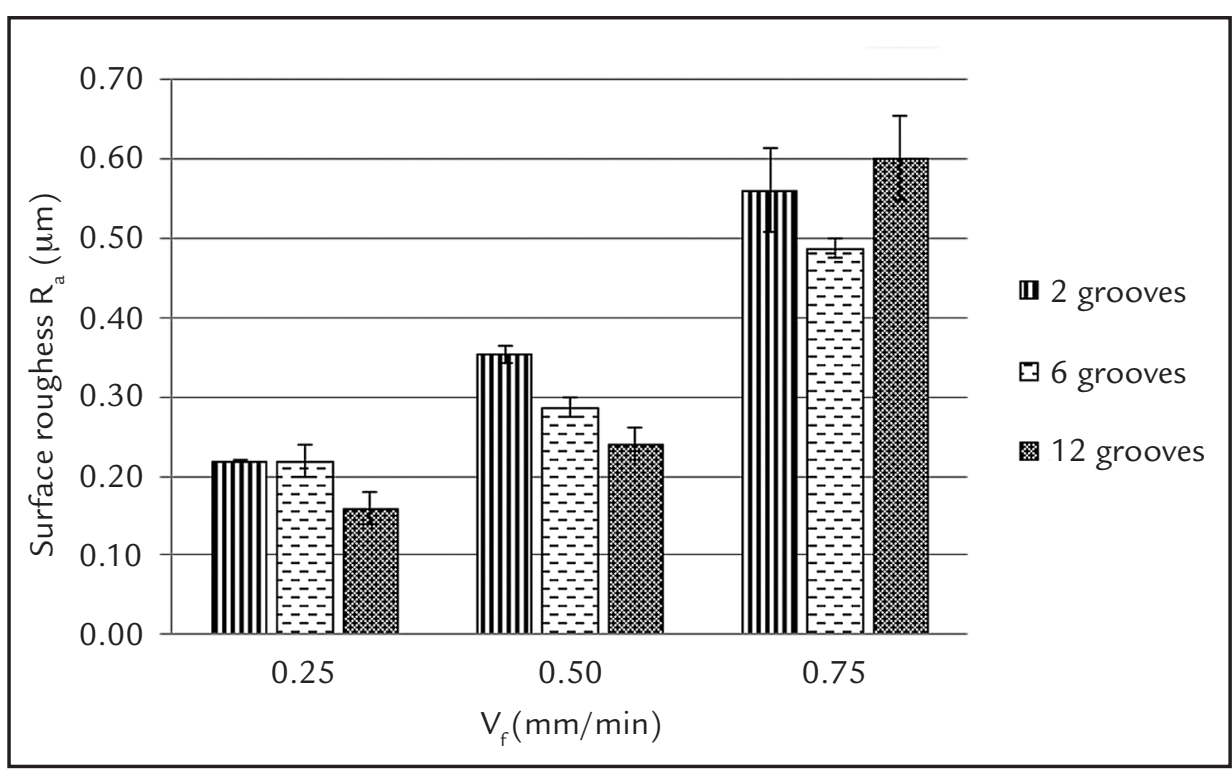

tool would generate impacts between them that might cause changes both in forces and surface roughness. According to Fan and Miller (2006), forces in an intermittent grinding process (with the grinding wheel grooves) are changed compared to conventional grinding (grinding wheel without grooves). The same author noted there was a decrease of average force and increase in force peaks for the intermittent process when compared to the conventional one, and conclude that the fewer the grooves, the smaller the average forces and the higher the peaks. And also, according to Tawakoli and Azarhoushang (2011), who studied the influence of intermittent grinding (grinding wheel with grooves) in the machining process of ceramic matrix composites (CMC), the surface roughness value for conventional grinding was slightly lower than for the intermittent process, explained by the constant hits between the abrasive tool - workpiece in the intermittent grinding. This is due to the coupling and uncoupling between the grinding wheel

samples for each trial and their standard

sive strain, facilitating its circular profile (ideal) deviations.

Comparing trials at the same infeed rate, it can be observed that an increase in groove density from two to six at 0.25 and $0.5 \mathrm{~mm} / \mathrm{min}$ speeds enhances roundness, which conversely decreases with twelve grooves. This fact is given due to a "low infeed rate", since the more grooves, the lower the external TS profile is. That way, 12-groove TS's have a lower profile and workpiece. However, when observing trials with the same infeed rate but different TS's, it appears that there is a trend of roughness decrease for removal rates of 0.25 and $0.50 \mathrm{~mm} / \mathrm{min}$, i.e. roughness decreases with the increase in groove number. At an infeed rate of $0.75 \mathrm{~mm} / \mathrm{min}$, for trials 03 ( 2 grooves) and 06 (6 grooves), a decreasing roughness trend was maintained; nevertheless, for trial 09 (12 grooves) it remained high. As the number of grooves grows at a certain infeed rate, there is less friction between the workpiece and wheel, resulting in higher peak forces (Fan and Miller, 2006) and lower temperature in cutting area by greater couplings and uncoupling frequency, promoting a cooling process. Perez et al. (2008), who when working with grooved wheels, concluded that the cutting temperature is reduced as the number of grooves on the wheel increase, which may be justified by a more effective coolant supply at the cutting area in intermittent compared to conventional grinding.; thus, reducing the surface roughness.

deviation are presented in Figure 3.2.a.

than the others, helping to reduce macrogeometric deviation.

In contrast, for $0.75 \mathrm{~mm} / \mathrm{min}$, increasing the groove number from two to six, promotes roundness values to increase, which also increases when using twelve grooves. This is the case of a higher infeed rate where a high level of mechanical stresses takes place, and the profile variation is observed for all grooved workpieces. According to Fernandes (2005), 
spark-out time implies in roundness deviation reduction. Higher spark-out periods (12 to 15 seconds) would result in minor deviations and would increase machining time, which can represent a capital loss to industry. The same author also found that in regards to conventional refrigeration, spark-out time alteration does not result in significant changes in roughness and wheel wear.
It can be observed from the roughness results that there is no defined trend among the infeed rates, that is, the roughness and roundness values tended to increase as the infeed rate increases, but when one assesses the results for a given infeed rate there is no consistent trend. However, smaller differences and a decreased measurement scale, hundredth of $\mu \mathrm{m}$, in roughness values can be noted. In

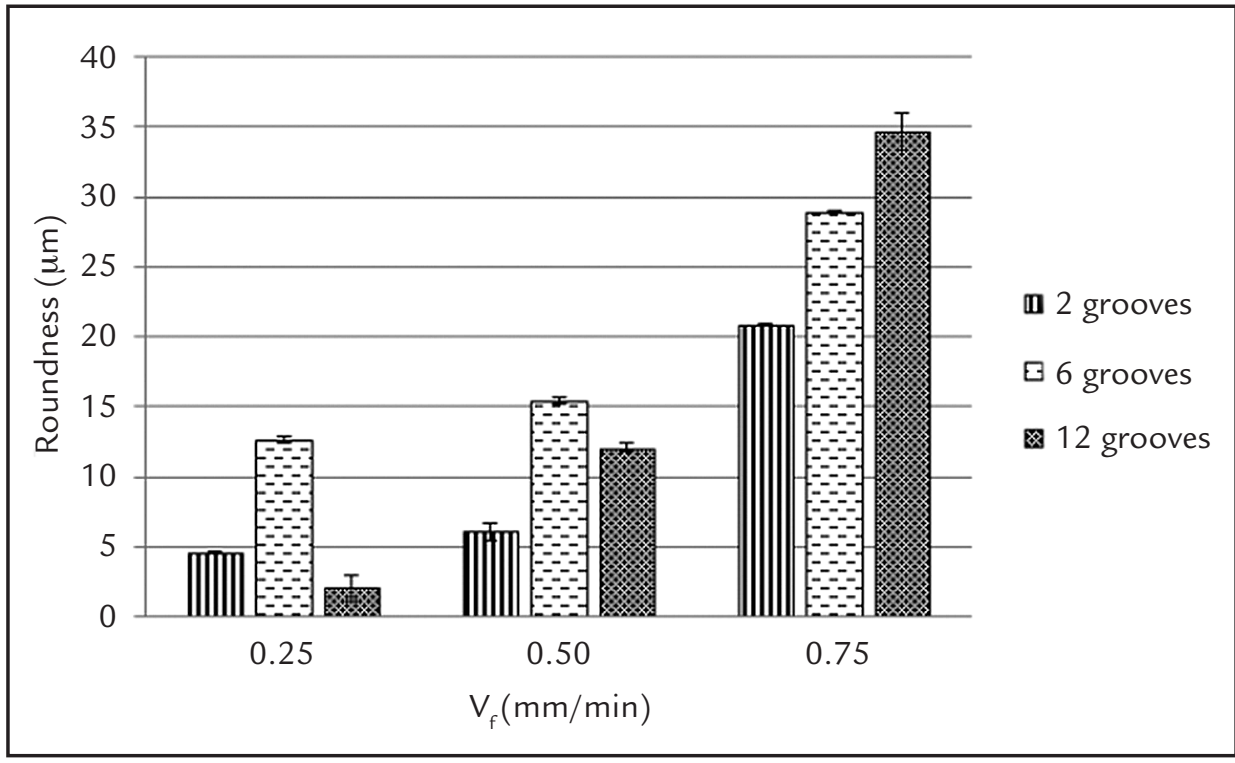

3.3 Diametral grinding wheel wear

Figure 3.3.a presents the grinding

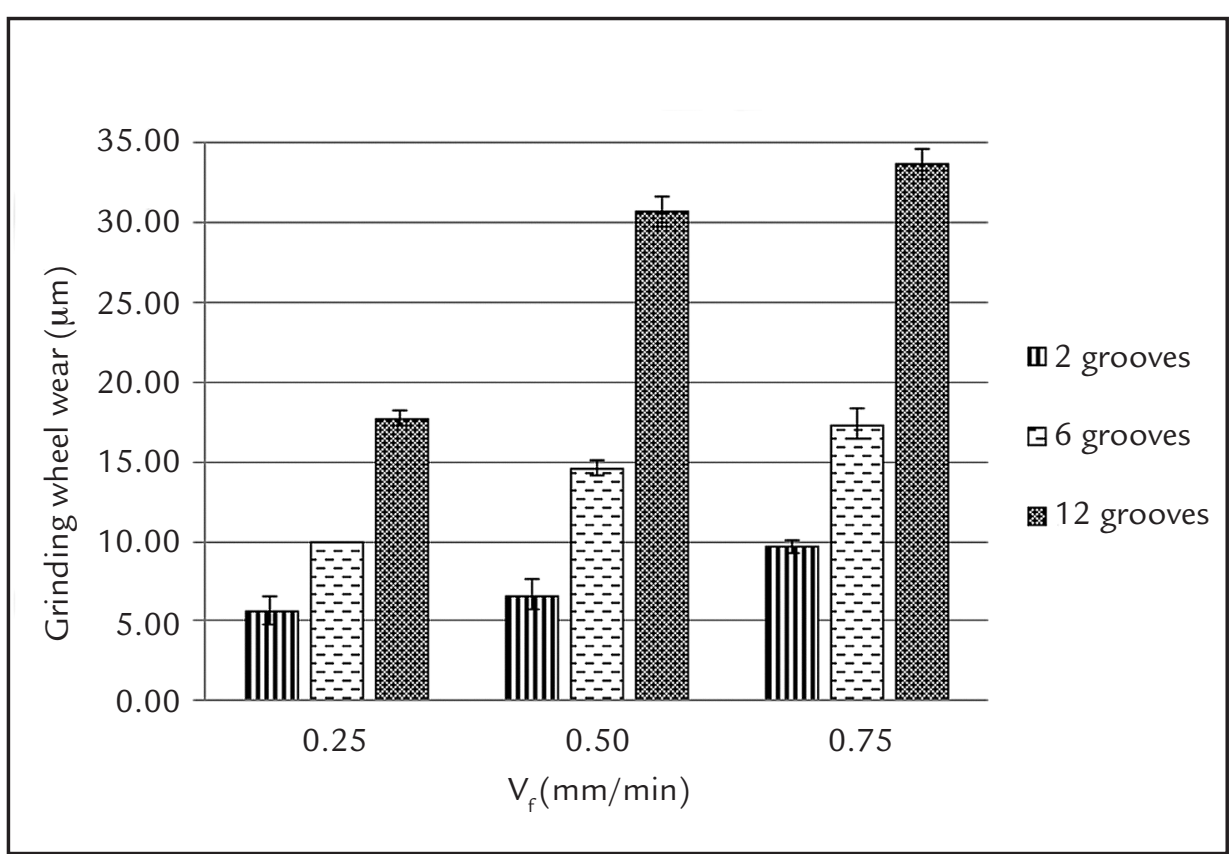

It can be seen that there is a trend of higher wear as infeed rate and groove number increase. This is because higher infeed rates and a greater number of grooves imply in further impacts on the wheel, increasing peak forces as described by Fan and Miller (2006). Additional impacts cause grain and bonder (vitrified) fractures resulting in wear. Moreover, by increasing the number of groves, the number of impacts against the wheel also grows due to coupling and uncoupling between tool and workpiece (Tawakoli and Azarhoushang, 2011), making the regard to the roundness values, the workpiece fixture plays an important role in the measurments performed, in other words, the ground workpiece is fixed to the chuck and when it is released, the stresses generated by the fixture setup are reflected in the roundness error. Nevertheless, the tendency of increase in roundness values as the infeed rate increases was possible to observe.

Figure 3.2.a

Roundness due to the grinding wheel infeed rate.

Figure 3.3.a

Diametral grinding wheel wearVs.

grinding operation most severe. As a basis, Liao et al. (2000) explains that wear occuring on the grinding wheel is related to abrasive grain breakdown and vitrified bonder fracture, both arising from thermal deterioration or severe mechanical stresses to which the wheel is subjected. 


\subsection{Power}

Figure 3.4.a shows results for the

Figure 3.4.a

Power consumed due to the grinding wheel infeed rate.

It can be seen that for the same groove number, there has been a trend of power consumption increase as tool infeed rate increased. On account of higher removal rates leading to greater efforts in the cutting area, as previously mentioned, and, in addition to greater friction, greater machine power is required to perform the machining process, which becomes more severe with the increasing removal rate.

Indeed, when analyzing Figure 3.4.a

\subsection{Microhardness}

Figures 3.5.a, 3.5.b and 3.5.c show the microhardness values for testing samples of 2-groove, 6-groove and 12 -groove, respectively.

It was observed that the microhardness below the ground surface remained unchanged, indicating that the microstructure right below the ground surface did not change significantly (i.e., the microstructure remained asquenched martensitic type). power applied in the process.

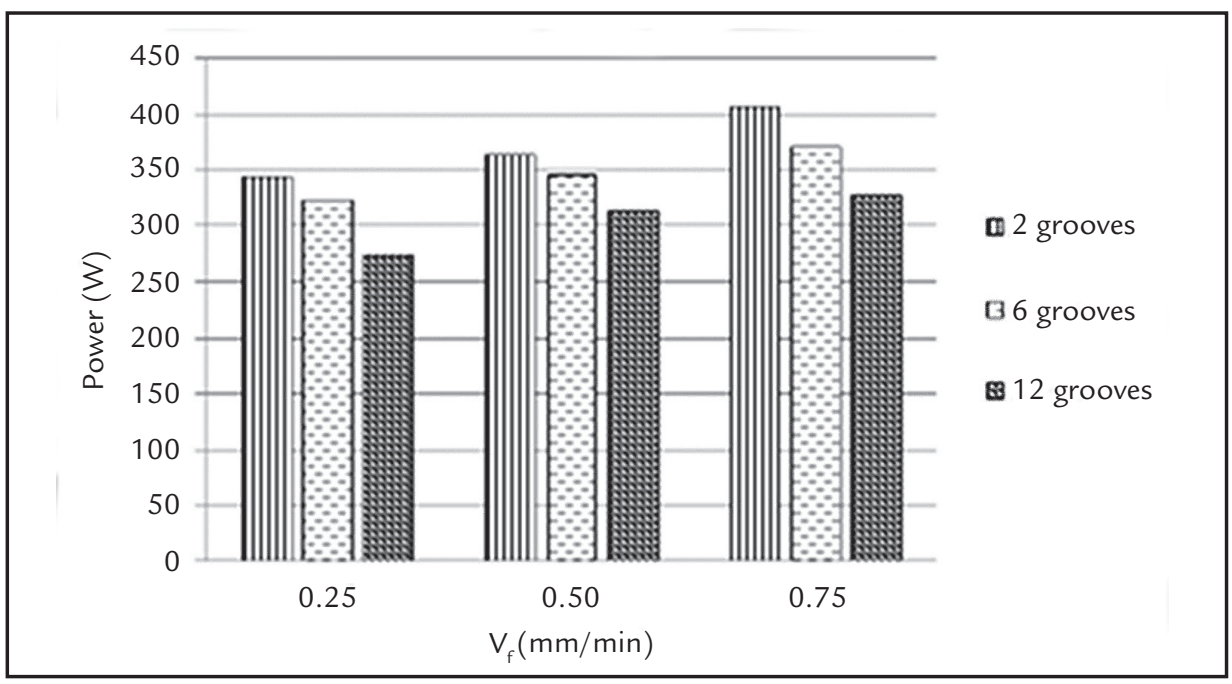

for the same infeed rate, it can be seen that there was a decreasing power requirement trend, for the three speeds $(0.25,0.50$, $0.75 \mathrm{~mm} / \mathrm{min}$ ), with an increasing number of grooves. This is explained by the lower contact area between workpiece and grinding wheel, as the number of grooves is higher, resulting in lower cut and friction effort and, therefore, less required power to perform the cutting operation.

These results are similar to the Fan and Miller (2006) study, who observed

As the purpose was to measure the possible changes in hardness on the workpiece surface, which could be affected by the heat generated during the grinding process, microhardness measurements were performed in HV (Vickers hardness) with a load of 300 grams, and a pyramidal diamond base, which ensure better precision of the measurements taken.

In this case, there is a slight modi- that a benefit commonly found in intermittent grinding (grooved wheel) is power reduction, which means that this wheel can work at high rates of material removal without exceeding the grinder limit power. Nakayama et al. (1977) attributed this power reduction to the thickest splinter and looseness to splinter flow, and concluded that the reduction of required power and better access of cutting fluid lead to a reduction of thermal damage to the machined area.

fication in microhardness at an infeed rate of $0.75 \mathrm{~mm} / \mathrm{min}$ (green line), with a mild reduction in hardness, indicating small microstructural changes, which can be explained by a slight "softening" in the microstructure, possibly caused by a carbon diffusion process for cementite aggregate $\left(\mathrm{Fe}_{3} \mathrm{C}\right)$ with a prevailing ferritic matrix area ( $\alpha$ phase), whose properties are high ductility and low hardness.
Figure 3.5.a Workpiece for 2-groove TS's.

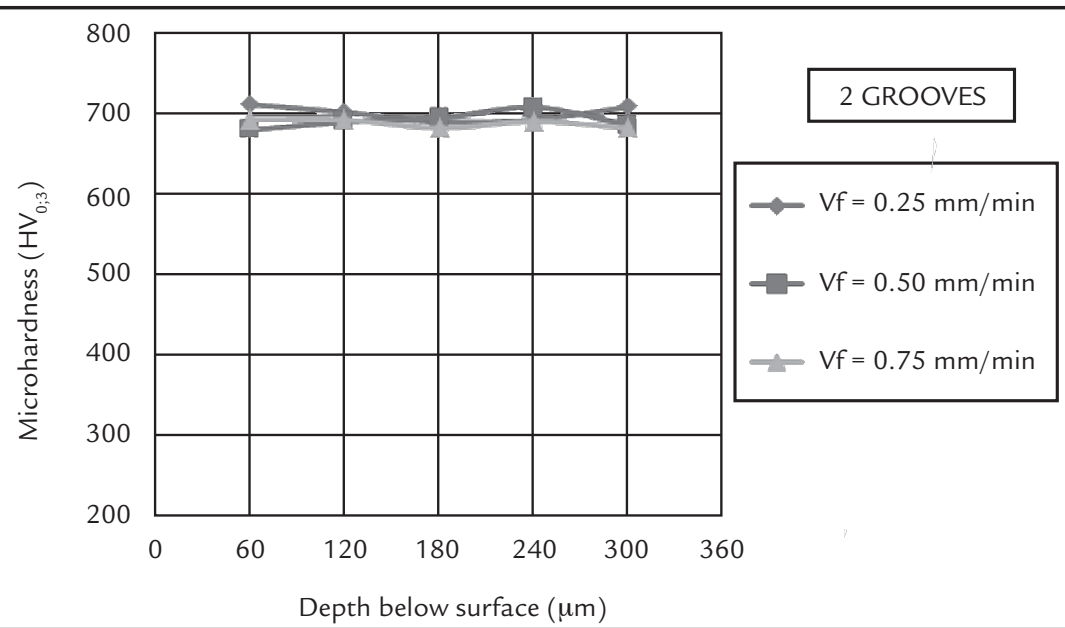

REM: R. Esc. Minas, Ouro Preto, 68(2), 229-238, apr. jun. | 2015 

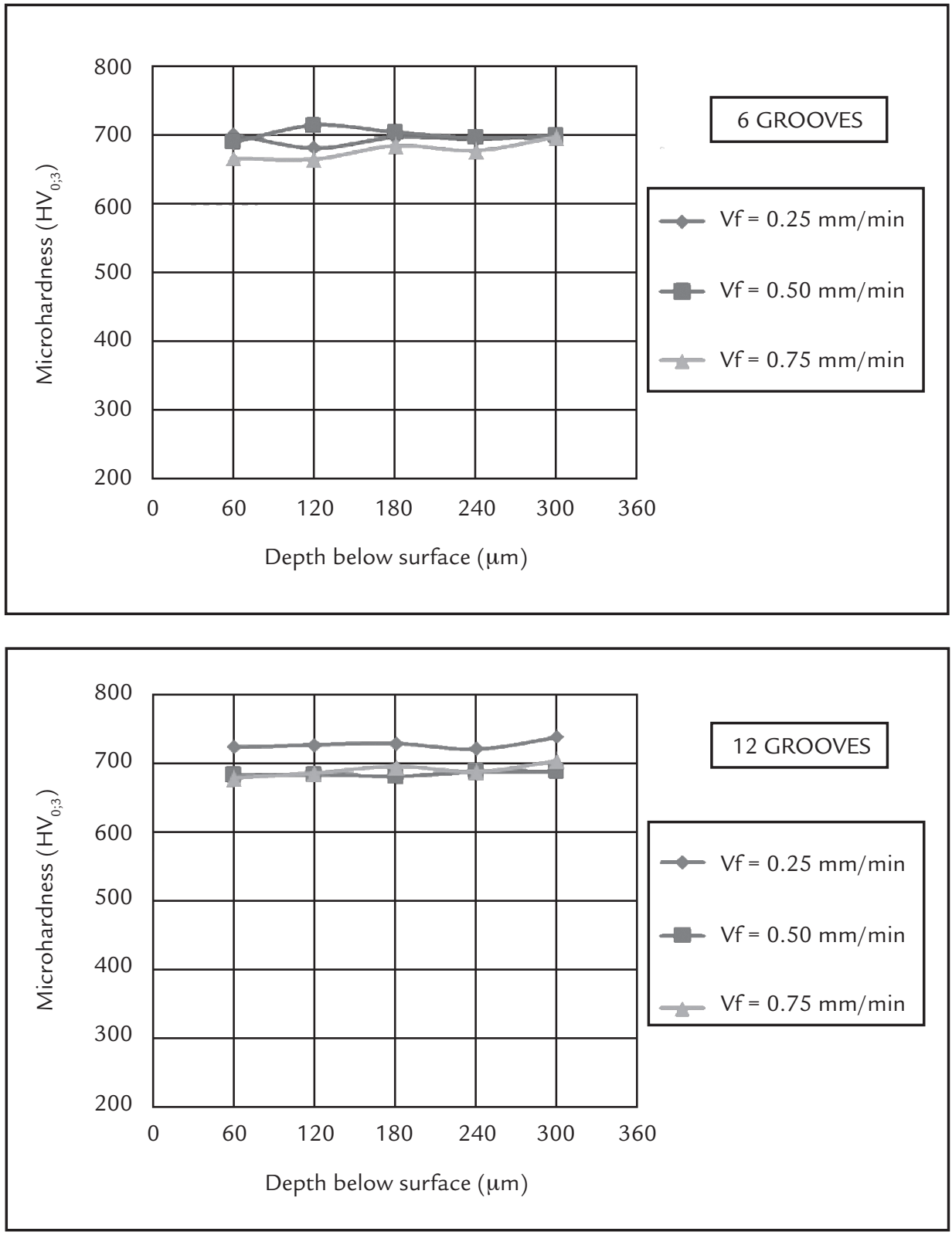

It was noted that there were no significant changes in infeed rates of 0.50 and $0.75 \mathrm{~mm} / \mathrm{min}$. However, at $0.25 \mathrm{~mm} /$ min rate, the hardness was higher than in all other cases. This may have been caused by errors in the workpiece's thermal treatment, before being subjected to testing, and it was not caused by subsurface overheating, since a micrograph test of TS did not display any burning process.

\subsection{Micrographs}

Shown by the Figures 3.6.a and

When the workpiece's surface being ground is exposed to high temperatures for a sufficient period of time, microstructural alterations may occur. In this aspect, the coolinglubrication conditions combined with the physical and mechanical properties of the wheel (primarily its thermal
Small changes in microhardness can be observed for all tests, which are usual to occur since the measurement is taken in different positions of the workpiece and also because of the non homogeneity of the material. This can be verified, for instance, in Figure 3.5.c for $0.25 \mathrm{~mm} / \mathrm{min}$ infeed rate and $60 \mu \mathrm{m}$ penetration, the microhardness value of $730 \mathrm{HV}$ is found. In other tests for other infeed rates of 0.50

3.6.b are the typical micrographs of micro-

conductivity) play a fundamental role in controlling temperatures and dissipating heat. According to Marinescu et al. (2004), grinding temperatures may not be high enough to cause visible burning; however, in severe conditions, the grinding temperatures may exceed the material tempering
Figure 3.5.b

Workpiece for 6-groove TS's.

Figure 3.5.c

Workpiece for 12-groove TS's.

and $0.75 \mathrm{~mm} / \mathrm{min}$, the microhardness value of $690 \mathrm{HV}$ can be observed, which implies a difference between the microhardness values less than $5.5 \%$. Small changes in microhardness also occur in other regions. However, one could infere these changes are not related to thermal damages because they are very small, but to measurement precision and the lack of the material homogeneity.

structures and surface conditions of TS's.

temperature, causing a reduction in the ground workpiece's surface hardness (softening).

When comparing the surfaces of ground pieces (Figs. 3.6.a and 3.6.b), it can be seen that the microstructure was unaltered in the regions close to the ground surface. 
Figure 3.6.a

Proof-body of 2 grooves and $\mathrm{Vf}=0.25 \mathrm{~mm} / \mathrm{min}$ micrograph.
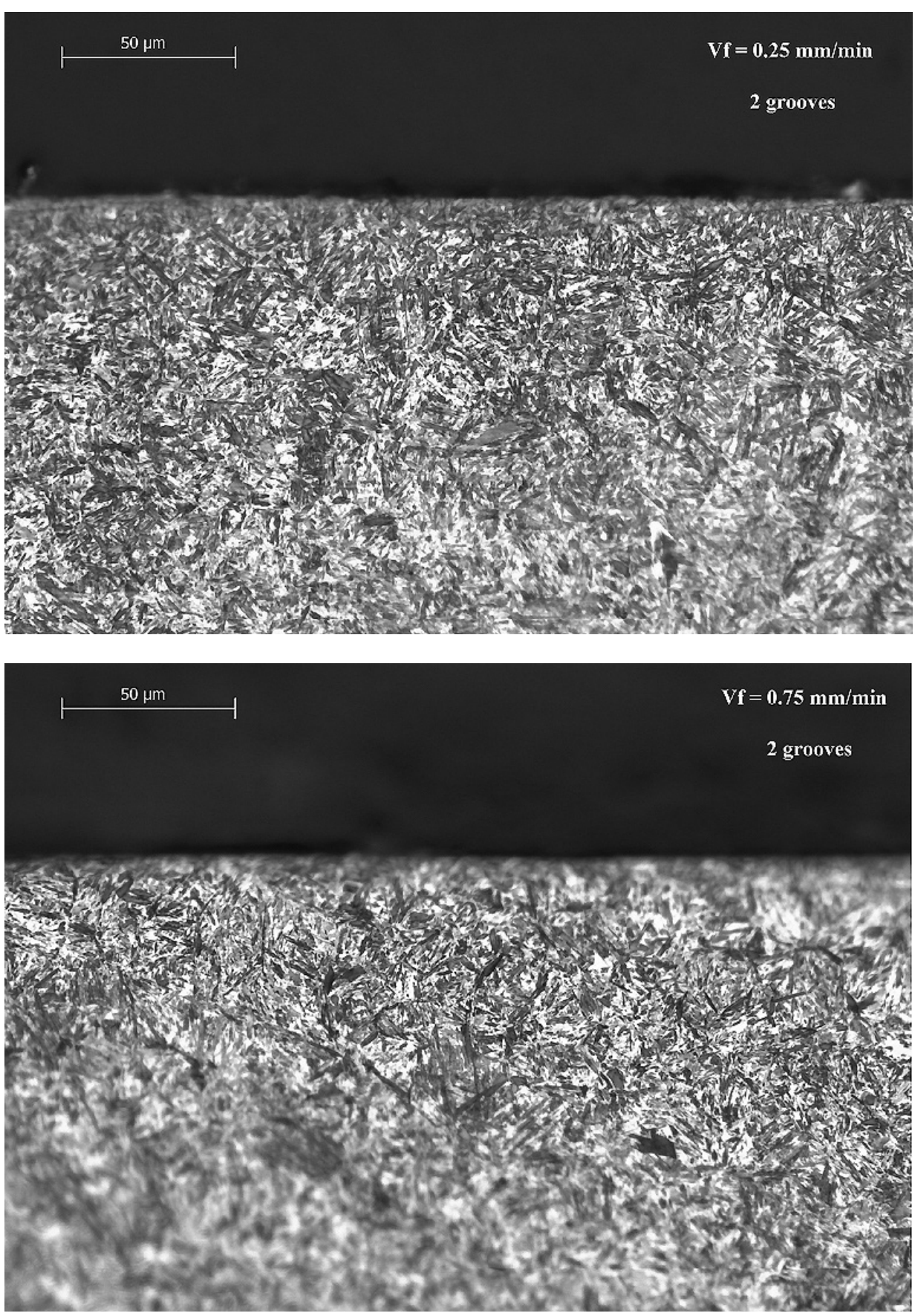

and $V f=0.75 \mathrm{~mm} / \mathrm{min}$ micrograph

\section{Conclusion}

From obtained results, it can be concluded:

When testing, sample roughness tends to improve as groove number and grinding wheel infeed rate increases, being the lowest roughness value obtained for 12 -groove TS's at $0.25 \mathrm{~mm} / \mathrm{min}$;

Just as roughness, roundness also tends to enhance as the infeed rate increases for the same groove number of

\section{Acknowledgements}

The authors would like to thank FAPESP (Research Support Foundation of São Paulo State, Process num-
TS's. The lowest roundness deviation $(2$ $\mu \mathrm{m})$ was also observed for 12-groove TS at $0.25 \mathrm{~mm} / \mathrm{min}$;

Grinding wheel wear enhances as the infeed rate and groove number increase, and minor wear was noted in trial at $0.25 \mathrm{~mm} / \mathrm{min}$ for 2 -groove TS;

Required power was greater as infeed rate reached higher levels for the same groove number of TS's. The lowest resupport to this research, NORTON Company for grinding wheel donation, ber: 2013/04006-3) for the financial quired power was observed for 12-groove TS at $0.25 \mathrm{~mm} / \mathrm{min}$ rate;

There were no expressive changes in microhardness of machined subsurfaces but for 12-groove TS at $0.25 \mathrm{~mm} / \mathrm{min}$, which has presented the highest values. It might possibly be due to errors during the workpiece's thermal treatment;

Micrographs revealed no significant changes on machined surface.

and JSC Tratamento Térmico Company for quenching and tempering the testing samples. 


\section{References}

AGOSTINHO, O. L., RODRIGUES, A. C. S., LIRANI, J. Tolerância, ajuste, desvios e análise de dimensões. São Paulo: Edgard Blücher, 1981.

ALVES, M. C. S., BIANCHI, E. C., AGUIAR, P. R. Influência da lubrirrefrigeração na qualidade superficial de metais retificados. REM. Revista Escola de Minas, v. 64, n. 4, p. 505-512, 2011.

AL-ZAHARNAH, I .T. Suppressing vibrations of machining processes in both feed and radial directions using an optimal control strategy: the case of interrupted cutting. Journal of Materials Processing Technology, v. 172, n. 2, p. 305-310, 2006.

BALDO, E. D. Redução do ciclo de retificação cilíndrica de mergulho com auxílio da emissão acústica. Campinas: UNICAMP, 1994. p.86 (Dissertação de Mestrado).

DINIZ, A. E., GOMES, D. M., ALDO BRAGHINI, Jr. Turning of hardened steel with interrupted and semi-interrupted cutting. Journal of Materials Processing Technology, v. 159, n. 2, p. 240-248, 2005.

DINIZ, A. E., MARCONDES, F. C., COPPINI, N. L. Tecnologia da usinagem dos materiais. Campinas: Artiliber Editora Ltda., (6. ed)., 2008.

FAN, X., MILLER, M. H. Force analysis for grinding with segmental wheels. Machining Science and Technology, v. 10, n. 4, p. 435-455, 2006.

FERNANDES, U. B. Análise da influência do tempo de centelhamento para diferentes métodos de refrigeração na retificação. Bauru, SP: Faculdade de Engenharia da UNESP - Campus de Bauru, Dissertação de Mestrado). 2005.

HASSUI, A. Estudo da vibração durante o corte e centelhamento na retificação cilíndrica de mergulho. Campinas: Faculdade de Engenharia Mecânica da Universidade Estadual de Campinas - UNICAMP, (Tese de Doutorado). 2002.

KIM, P., JUNG, J., LEE, S., SEOK, J. Stability and bifurcation analyses of chatter vibrations in a nonlinear cylindrical traverse grinding process. Journal of Sound and Vibration, v. 332, n. 15, p. 3879-3896, 2013.

KLOCKE, F., BRINKSMEIER, E., WEINERT, K. Capability profile of hard cutting and grinding processes. CIRP Annals - Manufacturing Technology, v. 54, n. 2, p. 22-45, 2005.

KOUNTANYA, R. Cutting tool temperatures in interrupted cutting - the effect of feed-direction modulation. Journal of Manufacturing Processes, v. 10, n. 2, p. 47$55,2008$.

KWAK, J., HA, M. Force modeling and machining characteristics of the intermittent grinding wheels. KSME International Journal, v. 15, n. 3, p. 351-356, 2001.

LIAO, T.W., LI, K., MCSPADDEN JR, S. B. Wear mechanisms of diamond abrasives during transition and steady stages in creep-feed grinding of structural ceramics, Wear, v. 242, n. 1-2, p. 28-37, 2000.

MARINESCU, I.D., ROWE, W.B., DIMITROV, B., INASAKI, I. Tribology of Abrasive Machining Processes. Norwich: William Andrew Inc., 2004.

NAKAYAMA, K., TAKAGI, J., ABE, T. Grinding wheel with helical grooves-an attempt to improve the grinding performance. In: CIRP. Annals... v. 25, n. 1, p. 133-138, 1977.

PÉREZ, J., HOYAS, S., SKURATOV, D. L.I RATIS, YU. L.l SELEZNEVA, I. A., FERNÁNDEZ DE CÓRDOBA, P., URCHUEGUÍA, J. F. Heat transfer analysis of intermittent grinding processes. International Journal of Heat and Mass Transfer, v. 51, n. 15-16, p. 4132-4138, 2008.

QUINTANA, G., CIURANA, J. Chatter in machining processes: a review. International Journal of Machine Tools \& Manufacture, v. 51, n. 5, p. 363-376, 2011.

SANCHES, H. A. B. Interrupted cutting turning process evaluation using frequencies and forces analysis. São Paulo: Escola Politécnica, University of São Paulo, 2011. (Dissertação de Mestrado em Engenharia Mecânica de Projeto de Fabricação).

TAWAKOLI, T.; AZARHOUSHANG, B. Intermittent grinding o ceramic matrix composites CMCs utilizing a developed segmented wheel. International Journal of Machine Tools \& Manufacture, v. 51, n. 2, p. 112-119, 2011.

Received: 08 May 2014 - Accepted: 17 March 2015. 